\title{
What Serves Best Kurdish Self-Interest in Turkey: An Analysis in Light of The American Experience of Becoming a Nation and The Role of Education
}

\author{
Prof. Dr. Mustafa ÖZCAN \\ MEF Üniversitesi, Eğitim Fakültesi, Ayazağa Cad., No:4, \\ Sarıyer / İstanbul / Türkiye
}

\begin{abstract}
The ending of the Cold War at the close of the 20th century became a turning point for the acceleration of racial, ethnic, and religious conflicts around the world, specifically in the Middle East. Within various countries, struggles have arisen, as diverse social groups demand political, cultural, and religious rights. Turkey is one of those countries. Representatives of the Kurds are demanding rights ranging from cultural recognition to political autonomy and independence. Some Kurdish groups are using terror to realize their goals. The tension stemming from this conflict is deteriorating the social, political, and cultural life of the country. The anomaly is that the Kurds have coexisted with the rest of the nation for more than one thousand year and their commonalities are more ample than their differences. America is a nation of immigrants from diverse racial, ethnic, and cultural backgrounds. They


have become blended and melted together to make America a Melting Pot or Salad Bowl. They learned to be American. Although America is considered one of the most democratic, peaceful, and rich countries of the world, America, in fact, has had many racial and ethnic problems. Black Americans were enslaved until 1865, and they did not have equal rights until 1965. Other minority groups-specifically non-white and non-European minorities-have always experienced prejudice and discrimination. However, despite these problems, none of these groups has used terror as a tool to realize their goals. None of the groups is struggling to divide America. Despite their racial, ethnic, and linguistic differences, how did Americans achieve this unity and civility? In this process, what are the roles of the metaphors of Melting Pot and Salad Bowl in the formation of educational policies? What can Turks and Kurds learn from the American experience of becoming a democratic nation? What is in the best interest of the Kurdish people in Turkey? This paper will investigate and discuss the answers of these questions.

Keywords: The kurds; Melting pot; Salad bowl; Cultural diversity; Education of minorities.

\title{
Türkiye'deki Kürtler'in Çıkarlarına En İyi Ne Hizmet \\ Eder: Amerikalıların Millet Olma Deneyimi ve Bu Süreçte Eğitimin Rolü Işığında Bir Analiz
}

\begin{abstract}
Özet
Soğuk Savaş'ın sona ermesi dünyada, özellikle de Orta Doğu'da ırka, etnik ve dini gerekçelere dayalı çatışmaları alevlendiren bir dönüm noktası oldu. Birçok ülkede farklı sosyal gruplar siyasi, kültürel ve dini haklar talep etmeye başladı. Bu ülkelerden birisi Türkiye'dir. Kürtleri temsil ettiklerini iddia eden gruplar kültürel farklılıkların tanınmasından siyasi bağımsızlığa kadar uzanan haklar talep etmeye başladılar. Üstelik bazı Kürt gruplar amaçlarını gerçekleştirmek için terörü bir araç olarak kullanmaktadır. Yoğun olarak 1984'ten beri devam eden bu çatışmaların yol açtığı gerginlik ülkenin sosyal, siyasi ve kültürel hayatını olumsuz şekilde etkilemekte, milli birliğe, ekonomi ve eğitime zarar vermektedir. Garip olan şudur ki Kürtler bin yıldan fazla bir zamandır bu topraklarda Türklerle birlikte yaşadılar, et ve tırnak gibi oldular ve Türklerle aralarındaki
\end{abstract}


benzerlikler farklılıklarından çok daha fazladır. Amerikalılar farklı soy, etnik köken ve kültürel gruplardan gelen göçmenlerden oluşan bir milletir. Bu gruplar bir potada eriyerek veya iyice karışarak bugün Eritme Potası (Melting Pot) ve Salata Kasesi (Salad Bowl) mecazlarıyla tanımlanan Amerikan milletini oluşturdular. Amerikan olmayı öğrendiler. Dışardan zengin, demokratik ve huzurlu görünen Amerika aslında her zaman ırkçılık ve etnik ayrımcılık sorunlarıyla uğraşan bir ülke olmuştur. Siyah Amerikalılar 1865'e kadar köle olarak yaşamış, 1965'e kadar yasalar önünde bile eşit olamamıştır. Diğer azınlıklar, özellikle de Avrupalı beyaz ırktan olmayan azınlıklar hemen her zaman ön yargı ve ayrımcılığa maruz kalmıştır. Ancak, bu problemlere rağmen bu grupların hiç birisi terörü kendi amaçlarına hizmet edecek bir araç olarak kullanmamıştır. Bu grupların hiç birisi kendi istediklerini almak için Amerika'yı bölme mücadelesi başlatmamıştır. Kendi aralarındaki soy, etnisite, din ve dil farklılıklarına rağmen Amerikalılar milli birliği nasıl başardı? Farklılıklarını ve çatışan çıkarlarını tartışırken bile demokratik ve medeni olmayı nasıl öğrendi. $\mathrm{Bu}$ süreçte Amerika'yı tanımlamak için kullanılan Eritme Potası ve Salata Kasesi kavramları eğitim politikalarına nasıl yansıdı? Türkler ve Kürtler daha demokratik bir millet olmak için Amerikan tecrübesinden ne öğrenebilir? Birlikte yaşamak mı yoksa bölünmek mi Kürtlerin çıkarına daha fazla hizmet eder? Bu makalede bu ve benzeri soruların cevapları aranacaktır.

Anahtar Kelimeler: Kürtler; Eritme potas1; Salata kasesi; Kültürel çeşitlilik; Azınlıkların eğitimi.

\section{Introduction}

The data used in this section is from the studies conducted by KONDA, a public opinion research company based in Turkey. One KONDA report entitled, "Kürtler and Kürt Sorunu" (Kurds and Kurdish Problem) was prepared by using two studies conducted in 2006 and 2008 (Ağırdır, 2008). One of these studies, "Biz Kimiz? / Toplumsal Yapı Araştırması," (Who Are We? / Social Structure Research) was conducted in 2006 by interviewing 47,958 participants living all over Turkey. In this study, the participants were asked, "We all are 
Turkish citizens, but we can be from different roots and regions. What do you call yourself, or how do you feel about your own identity?". According to the report, 8.6 percent of the participants called themselves "Kürt" (Kurd) and 0.41 percent called themselves "Zaza" -a small group usually classified within larger Kurdish community. Those who call themselves Kurd or Zaza make up 9.01 percent of total adult population in Turkey- approximately 6,345,000 people. Participants were asked similar questions about their native language. KONDA crosschecked the responses about the language and identity and calculated the ratio of children by using census data from the year 2000. Overall, KONDA concluded that, as of 2007, about 11 million of the 70,506,000 people living in Turkey define themselves as either Kurd or Zaza, which is 15.7 percent of the total population. Out of this Kurdish population, 66 percent lives in Anatolia-located in the eastern part of the country. The remaining 34 percent lives in the rest of the country. Outside of the eastern part of the country, the largest group of Kurds lives in Istanbul. They make up around 14.8 percent of the population of Istanbul, which is approximately 1.9 million people. A very large portion of the Kurdish citizens can speak Turkish. The number of those who does not speak Turkish is about $1,350,000$ people.

According to the KONDA's other study, "Who Are We? Life Styles Research," which was conducted in 2008 , the average period of education of a Turk is 7.4 years while the average period of education for a Kurd is 6.1 years. The study found that 24 percent of Kurds liv- 
ing in villages do not know how to read or write. Another significant finding regards intermarriage between Turks and Kurds. According to this research, the number of Kurds who have Turkish relatives is $2,600,000$, which is 3.7 percent of total population. This finding is important because the number of adults that call themselves Kurd or Zaza, as stated above, is approximately 6,345,000, which is 9.01 percent of the total population. These findings mean that, in Turkey, there are 6,345,000 adults (people eligible for marriage) who call themselves Kurds (or Zaza) and 2,600,000 of them (that is, 40.9 percent of the Kurdish adult population) have Turkish relatives. The ratio of Turkish and Kurdish relatives is higher than the corresponding ratios of relatives between white Americans and other ethnic groups (Statistical Abstracts of the U.S., 2010).

\section{Racial Roots of Turks and Kurds}

In America, racial categories, such as "White," "Black," "Brown," and "Asian" are commonly accepted and frequently referred to. Blacks are black-skinned descendants of Africans. Asians are people of East Asian descent. Browns are descendants of Latin America. Whites are European, Middle Eastern, and Central Asian peoples, including Turks, Arabs, Iranians, Jews, and Kurds. In the eyes of a typical American, Turks and Kurds are from the same White race but have ethnic differences. Between White Americans and Black Americans, there is a racial difference. For centuries, White Americans believed that Blacks were biologically inferior (Miller, 1997). Moreover, between White Americans and Asian Americans, there is a racial dif- 
ference in addition to cultural (linguistic, religious, traditional and the like) differences. Similarly, in addition to cultural differences, there is a racial difference between White Americans and mixed-race Brown Americans. It seems that, despite these racial and ethnic differences, within a few centuries, policies and social conditions made the building of a nation possible. However, the policies and social conditions have better served Whites in the journey of becoming a homogeneous nation. In light of this experience, it is expected that mixing and blending between Kurds and Turks, as both are White, would be analogous to that of the mixing of white ethnic groups in America (Banks, 2005). This expectation is supported by the high intermarriage ratio given above.

\section{One Thousand Years in Anatolia}

Turks and Kurds have lived together in Anatolia for more than one thousand years. There are multiple sources citing the early interfaces between these two groups. According to one source (Özer, 2009, s.43-44, 57), Muslim Arab armies came from Arabistan and defeated the Kurds in the Hamedan and Rey regions in 640. This information implies that the Kurds were one of the communities living in Central Asia, which is the homeland of the Turks. Later in the first half of the $11^{\text {th }}$ century, Turks and Kurds met in the western part of Iran. Before the $11^{\text {th }}$ century, they both served in the armies of Muslim Arabs (in the armies of "Halife" and "Gazneli"). Tugrul Bey (995-1063), the Sultan of Seljuk Turks cooperated with the local Kurdish population. The local Kurds supported Alparslan (1039-1072), the Sultan of the 
Seljuks, against the Byzantium Empire in the "Malazgirt War." According to the same source (Özer, 2009, p.50), for the first time in history, Sencer Bey (1087-1157), the Sultan of Seljuks, established a province (eyalet) called "Kurdistan." This province included the "Dinaver, Sehrizor, Sincar, Kirmansah, and Hamedan" regions. ${ }^{1}$ During the Seljuks and Ottomans, Turks and Kurds lived together as citizens of the same empire for about one thousand years. They served in the same army, defended the same territories, married one another, believed in the same religion, and blended in many ways. During the First World War and the War of Independence following it, they fought together against the occupying armies.

\section{Turkish and Kurdish Cultures}

Culture is the most important determinant of ethnic identity (Harris and Johnson, 2000; Klein and Edgar, 2002). Do Turkish and Kurdish cultures differ from one another? To answer this question, the meaning of culture, as it is understood in this paper, should be explained. Culture is a community's program to survive and prosper; it includes material and non-material tools and sources to meet the needs of the community. Culture can be divided into some basic components, such as language, religion, education, values, traditions, economy, literature, food, music, dance, clothing, etc. (Brislin, 1993). In Kurdish and Turkish communities, some of these components are similar, but others are different. At this point, a vitally important question is: Are the cultural differences between Turks and Kurds starker

\footnotetext{
${ }^{1}$ This source, (Ozer, 2009) does not give any specific date for the establishment of the first province called "Kurdistan" in the Selcuks Empire by Sencer Sultan in the $11^{\text {th }}$ century.
} 
than cultural differences between French and German, Irish and Greek or English and Italian peoples-all who have immigrated to America? These ethnic groups were once very different from one another. The only common feature among them was their White-racial background. Also, they were all Christians, but some were Catholic. Others were Protestants, who were divided into many churches. In addition, many of the European nations had been at war with one another and were the enemies of each other (Steinfield, 1970). These diverse groups immigrated to America, blended and melted together, and created a new nation. Instead of living a clannish life, joining together and uniting as a nation was in their best interest. Turks and Kurds have so many common cultural values. For example, they are both Muslim, and they have common cultural elements in music, dance, traditions, and celebrations. They have lived in the same homeland, and they have expanded their homeland by political victories. They have defended their homeland against the enemies. Furthermore, their ancestors have been sleeping in the same cemeteries for one thousand years.

\section{Emergence of the American Nation}

Americans are a nation of immigrants. The oldest "immigrants" to America are the Native Americans. Thousands of years ago they migrated from Asia to America through the Bering Strait. ${ }^{2}$ Historically, there were about 500 Native American tribes with different

\footnotetext{
2 The research on the time and route of the Native American immigration is not conclusive yet. There are different ideas regarding the date of their immigration. The suggestions of scholars about the date of the Native American immigrations from Asia are ranging from 15 to 40 thousands years back in history. On the other hand, among the Native Americans there is a common inclination to believe that as human being they had originated in America and they are the only native of the continent.
} 
languages, customs, and traditions. However, today the total number of Native American tribes is around 300. They live around the continent, and there are cultural and linguistic differences among them. There are several large Native American tribes, but most of them are small. Some of them have lost their native language. Most of the $\mathrm{Na}$ tive American population that once lived on Native American reservations has immigrated to big cities, and the percentage of those still living in the reservations is now less than 25 percent (Banks, 2005). Of the total population of the United States, Native Americans are less than one percent.

Despite the seniority of the Native Americans, the United States of America was established by European immigrants after the discovery (or rediscovery) of America by Christopher Columbus in 1492 (Banks, 2005). European immigrants began to come to America in the $15^{\text {th }}$ century. In the following centuries, immigration to America has continued. Immigrants from Europe have been peoples from various nations. For example, they are Spanish, English, Irish, German, French, Dutch, Swedish, Polish, Italian, Russian, Jewish, and so on. They belong to different nations with diverse cultures (languages, customs, religions, music, foods, etc.). There was neither an American nation in Europe, nor was there a country called America in any place on earth. First, European immigrants established various states on the eastern side of the North America. These were the colonies of England. On July $4^{\text {th }} 1776$, all 13 states came together to establish the United States of America by signing the Declaration of Independence. 
The American Constitutional Convention began deliberations on May 25, 1787, prepared the current American Constitution, and dissolved itself on March 4, 1789. In the following years, European immigrants conquered the rest of the continent, and the number of states reached 50. All the states joined the Union. At the beginning of the immigration wave to the United States, and even in 1776, the immigrants to America were very diverse. In the following two centuries, despite their racial, ethnic and cultural differences, these immigrants were melted and blended together and re-emerged as a new nation. Today, America, with its population of 310 million, is a united and strong nation (Statistical Abstracts of the U.S, 2012).

\section{Demographic Status of Ethnic Groups in America}

As of a 2010 projection, the total population of the United States is 310 million. The distribution of this population by racial and ethnic groups is as follows: White: 200,853,000

Hispanic:49,726,000, Black:39,909,000, Asian:14,415,000, American Indian and Alaska Native:3,188,000, Two or more Races:5,499, 000 and Native Hawaiian and other Pacific Islander:592,000 (Statistical Abstracts of the U.S, 2012, Table 12).

According to the demographic projections of the U.S. Census Bureau, the total population of the U.S. in 2050 will be 439 million. Also, in 2050, the ratio of White and non-white Americans will be about equal. In other words, the half of the American population will be of White European origin, and the other half will be composed by 
non-European and non-white Americans. Of the non-white Americans in 2050, about 25 percent will be Hispanic Americans, who will comprise than 100 million individuals (Statistical Abstracts of the U.S, 2010, Table 3).

\section{Why Immigrants Have Become Americans}

As scholars, we are ethically responsible for proposing solutions to the growing ethnic conflicts around the world. To produce knowledge-based, viable ideas, we need to understand the racial and ethnic interactions that, in America, gave way to the formation of one nation out of many. At this point, a significant question is: Why did the immigrants give up their already-established national identities to adopt a new identity? They had left their homeland for economic, political, or religious reasons but not to replace their culture or language. These immigrants gradually forgot their native language, music, customs, and traditions. They began speaking English and learned the American way of life. In other words, maybe not all, but a huge majority of them have assimilated to a new nation.

To understand any social event, we need to understand the motivation behind it (Weber, 1978). The question of what motivated immigrants to assimilate leads us to another question, which is deeper than the first one: Why do human beings do or not do something? At this point, we should remember that humans are rational beings who live with values. As rational beings, humans want to survive, grow, utilize their potential, and realize their dreams. To survive and realize their potential, humans need different kinds of material and 
non-material resources. They always look for and strive to find the sources that are needed for their survival and growth. These sources can come in many forms, such as economic, political, honorific, psychological, cultural, religious, and so on. The motivation to strive to survive and utilize their potential is a common feature of all living beings. However, humans also have values oriented towards survival and growth that guide them in their actions (Özcan, 1996). According to Max Weber (1978), self-interest creates the motivation for human action, and ideas determine the direction of the action. In other words, the first impulse or urge to act is created by the possibility of satisfying human self-interest; however, this is not enough for the realization of the action. Values determine the fate and direction of human action. This perspective can be helpful to understand the assimilation of immigrants into American society. The issue will be discussed from this perspective in the following paragraph.

America is a rich and democratic country with many appealing features. As a matter of fact, America was not so rich and democratic in most of her history. Specifically from the beginning of $16^{\text {th }}$ to the mid $20^{\text {th }}$ century, life was not easy for new immigrants, particularly for non-white minorities. First of all, the early immigrants were not wealthy. Travel from Europe to America was long, difficult, and expensive. The immigrants had to work long hours to pay their survival expenses. Finding a job required speaking the language of the community. English was the most commonly spoken language, alongside German and French. English was also the language of instruction in 
most schools. Likewise, English was used in most churches. Most of the owners of the plantations who needed workers also spoke English. In this kind of a social, economic, and cultural context, for the new immigrants, learning how to speak English alongside learning the way of life commonly practiced in the community were necessities to survive. There was no law, police force, or militia forcing immigrants to give up their language and traditions, but it was a de facto necessity. Learning the language, customs, and way of life commonly practiced in the community was in the best interest of the immigrants. Otherwise, they would not be able to actively participate in the life of the community or sufficiently utilize their potential. Furthermore, their merits would not be recognized, honored, or rewarded. Most importantly, their dream of a better life in America would not be realized. Also, keeping in touch with their relatives, friends, and the previous ethnic community was very difficult. To facilitate their connections with the people practicing their native culture in the previous homeland, technological devices such as TV, Internet, cell phones did not exist. Visiting the homeland was not easy either. Under these conditions, for the new immigrants to survive and prosper, assimilation into the culture of the majority was the best option available.

\section{The Metaphor of the Melting Pot}

The second significant question to understand the process of ethnic interaction and the creation of a new nation in America is: How did the immigrants become American? Americanization -or, the process of the assimilation of immigrants into mainstream society- has 
been observed, explained, and interpreted by many scholars, politicians, authors, and artists. Although there are many terms used as metaphors or symbols to explain the phenomenon of Americanization, the Melting Pot has been very popular and commonly used. The first instance of the use of the notion of the Melting Pot was by J. Hector St. John de Crevecoeur, a French-American in 1782. Crevecoeur (1957) in an effort to explain the creation of a new nation in America in his Letters from an American Farmer. Written in 1782, these letters sought to answer the question, "What ... is the American, this new man?" In these writings, he used the word "melt" to describe the process of forming a new nation. He wrote, "Here individuals of all nations are melted into a new race of men." After Crevecoeur, DeWitt Clinton used the word "melt" to explain how the English language was melting diverse groups into one people (Gleason, 1964). Later in the 1840s, an American Congressman described the process of Americanization by saying that the immigrants, instead of clannishly preserving their own identity, melted into the mass of the American population (Curti, 1946 cited in Gleason, 1964). Throughout the $19^{\text {th }}$ century, there were others using the term Melting Pot or some alternative term, such as "crucible" to describe the process of Americanization. However, until 1908, the term Melting Pot was not commonly adopted or popularized (Gleason, 1964; Banks, 2004).

On October 5, 1908, Israel Zangwill's play The Melting Pot opened in Washington, D.C. American President Theodore Roosevelt watched the play with Oscar Straus, the Secretary of Labor and Com- 
merce. Both Roosevelt and Straus praised it as a great and powerful play (Gleason, 1964). Upon the request of Roosevelt, Zangwill re-wrote a few lines of the play, and the play moved first to Chicago then later, in 1909, to New York. The Melting Pot became very popular and played for years. According to one critic, it was a play of the people, "touched with the fire of democracy, and lighted radiantly with the national vision" (Survey XXIII (p. 168), cited in Gleason, 1964). By the play Melting Pot, Israel Zangwill, an English Jew, captured the American spirit and gave the nation a new symbol. According to Zangwill, America was "God's Crucible, the great Melting Pot" where all the races of Europe were melting and re-forming. He asserted that the real American, the coming superman, would be formed by the fusion of all races (Gleason, 1964).

After 1908, the term Melting Pot became commonly and frequently used as a metaphor to explain the formation of the American nation. This common usage does not mean that the metaphor of the Melting Pot has been universally accepted. There are scholars and lay people who think that this term is insufficient to represent the American experience of racial and ethnic blending and becoming a nation. Several scholars have suggested various alternative terms to replace the Melting Pot. Gleason (1964) classified the suggested terms into five categories, as follows: (1) Culinary terms: pressure-cooker, stew, soup, salad or salad bowl, and mixing bowl. (2) Color terms: flower garden, mosaic, kaleidoscope, cultural rainbow, and irradiation. (3) Musical terms: orchestra, and the choir of dance of the nations. (4) 
Mechanical terms: weaving machine, and pipeline. (5) Derogatory terms: dumping ground, village pound, catch-basin, and cul-de-sac. Gleason made this classification in 1964. Since 1964, some of these terms have been forgotten; some of them have become popular; and some new terms, such as cultural pluralism, patchwork quilt, and multiculturalism have been suggested (Banks, 2007).

\section{The Role of Education: Common School as Melting Pot}

By the popular media, the Melting Pot has almost always been portrayed in the same way: a large boiling pot and, under it, burning wood, fire and flames with lines of people from diverse nations, races and ethnic groups jumping into the boiling pot and a new human figure -the American- emerging from the pot. It is hard to explain why people have imagined this social and historical process in such a simple, rough, and harsh way and why the popular media has childishly portrayed it as such. It seems that this image of a boiling pot reflected the perceived need of America by the lay people as well as by the intellectuals and politicians. America was established as a nation state, but it was not yet a homogeneous American nation. The people living in the thirteen states that declared the independence of the United States of America on July $4^{\text {th }}, 1776$ did not constitute a homogeneous nation. The leaders of the thirteen states reached the agreement to establish the United States after long debates and many compromises. Both lay people and the leaders of those states were aware of the need for a homogeneous nation to protect their fragile new state and its independence. This oversimplified, albeit famous, image of the 
Melting Pot reflects what the Founding Fathers of America imagined for the future of the nation.

The phenomenon that has been experienced in America and symbolized by the metaphor of the Melting Pot is, in fact, an educational process-a learning experience, which occurs through the learning of a new culture, a new way of life. Therefore, instead of an image of a boiling pot, an image of a school would better describe the American experience of becoming a nation. Of course, assimilation into a new society involves more than the learning of a new culture. Interracial and interethnic marriages can also contribute to assimilation. However, race is not enough to make a person feel a sense of belonging to a nation. The most important element that makes a person a member of a given nation is culture, which is learned and which shapes the thoughts, values, and behaviors of that person. In other words, the blood in our veins is not enough to make us American, Turkish, German or Russian. More accurately, genes determine our biological characteristics, such as gender, skin color, eye color, and so on, but they cannot make us American, Turkish or Chinese. In order to be Turkish, American, or Chinese, we must learn and live the culture of that particular nation (Harris and Johnson, 2000). In modern society, the basic missions of public school are to teach the culture of the nation and to facilitate the identification of children, regardless of their racial or ethnic origin, with the nation. Research shows that individuals that learn the same kind of knowledge, values, and skills through formal education display the same kind of dispositions re- 
gardless of their racial or ethnic origins (Miller, 1997; Gleason, 1964; Banks, 2005; Huntington, 2004).

\section{The Success and Failure of the Melting Pot Policy}

The Melting Pot is not only a symbol that represents the experience of Americanization, but also it has been a policy of the American government. The founders of the United States of America were immigrants from Northern European countries. They were racially White, religiously Christian, but ethnically diverse. The Puritans (a dominant religious congregation) are frequently cited as among the founders of America and, in particular, as the founders of the capitalist economic system in the U.S.A. (Weber, 1995). The early immigrants from Northern Europe, who were the founders of the U.S, were also the gatekeepers for America. They were concerned about the intensity and growing diversity among immigrants, and, as such, they established policies to guarantee the unity, well being, and future of the nation.

Nation building requires a homogeneous community with a common culture, language, and customs. The founders and leaders of America were well aware that there was not an American nation, but one was emerging. The formation of the nation was being facilitated by the Melting Pot policy. The Puritans, in particular, believed that America was "the last and best hope of humanity." They would establish "the Kingdom of God" in America. They believed that the future of American national unity, democracy, and economy was dependent on the Americanization of the new immigrants as quickly as possible. 
As Calvinist Puritans, they also believed that they were the God's chosen people. They were convinced that God was pleased by their conduct because God had rewarded them with economic wealth, political power, and social honor. These rewards of God were indicators that Calvinist Puritans were predestined for Heaven. Since they were a chosen people, the Calvinists believed that all others, including the new immigrants, should adopt their way of life-the WASP (White Anglo-Saxon Protestant) culture. The belief of that they were "the best" justified an assimilationist policy, and the metaphor of Melting Pot has been used to explain the process. In the following paragraphs, the success and failure of the Melting Pot policy will be discussed by examining the experiences of specific racial and ethnic groups.

\section{White Ethnic Groups and the Melting Pot}

The Melting Pot policy was very successful in assimilating European ethnic groups and making them Americans. European ethnic groups immigrated to America in large numbers. They were from various nations in Europe. They all were White and Christian. In a few generations, they all mostly gave up their European-ethnic cultures and became Americans. They have been assimilated through both intermarriage and cultural conversion. Today, in America, when a typical White American is questioned about her or his racial and ethnic background, a typical response would be as follows: "I am 50 percent English, 30 percent German, and 20 percent French." If she/he were questioned about her/his native language, a typical answer would be: "I know a few words, but I cannot speak German or French." Another 
random White American may answer the same question as follows: "I am 25 percent Greek, 25 percent Irish, and 50 percent Swedish, but I can only speak English.” In general, typical White Americans nostalgically remember their ethnic backgrounds but do not know the features of their ancestral-ethnic cultures (language, music, foods, etc.).

The assimilation of the White ethnic groups from Europe was successful, but it was not a smooth process (Steinfield, 1970). The White ethnic groups experienced many ethnic, religious, and social class-based conflicts. As gatekeepers, White Americans from the northern European countries were reluctant to consider the immigrants from southern and eastern Europe as white. For example, according to these Americans of northern European ancestry, southern Italians were one of the most mixed races of Europe. They were "partly African, owing to the negroid migration from Carthage to Italy." The Modern Greeks were "by no means the Greek of the time of Pericles, neither in race nor temperament." Hebrews were "an Asiatic race." On the other hand, Syrian, Chinese, Japanese, and Hindu people were "more removed from the civilization of northern Europe and America" (Hall, 1912). From a different perspective, it can be said that these Americans of northern European ancestry did not want to share the privileges of the white majority with these new immigrants, and, as such, they resisted the recognition of Irish, Greek, Italian, Polish, and other people as white Americans (Miller, 1997). However, eventually they were all assimilated, and now they all are Americans. 


\section{Non-White Ethnic Groups and the Melting Pot}

During the centuries following the discovery of America, most of the immigration to the continent was from Europe. However, there were also other peoples and immigrants from non-European countries and from non-white races and ethnic groups. In the $20^{\text {th }}$ century, the origin and demographic characteristics of immigrants to America dramatically shifted from European countries to non-European countries. In a sense, now, in the U.S., there are people from all over the world. The larger racial and ethnic groups, who are also officially recognized and classified by the U.S. Census Bureau, are European Americans (Whites), Hispanic Americans, African Americans (Blacks), Asian Americans, and Native Americans. The U.S. Census Bureau recently added "Mixed Race" as a new category to this list. The Melting Pot policy, as mentioned above, worked successfully for the White and Christian immigrants who came from Europe. However, it is hard to say whether the Melting Pot has worked for all other racial and ethnic groups. Some scholars call them "un-melted" groups. In fact, they all have been melted, but in a sense, they are melted differently and to different extents. In the following paragraphs, the impact of the Melting Pot policy on African Americans will be discussed.

Before 1776, most African Americans were brought by European Americans to America as slaves (Hall, 1912). Some scholars classify them, together with Native Americans and some Hispanic Americans, as "involuntary minorities" (Ogbu, 2003). From the early days 
of the slave trade in the mid- $16^{\text {th }}$ century to the end of the American Civil War in 1865, all African Americans (with very few exceptions) were slaves. Slaves were the property of slave owners-similar to houses, land, or animals. They were bought and sold. In some states, learning how to read and write was forbidden to them. In a period of slavery lasting more than 250 years, they lost everything making them belong to an African ethnic group. Their cultures, that is, their language, traditions, family structure, food, music, and everything else making them an African cultural community were totally lost. The only thing from Africa that they did not lose was the color of their skin.

Slavery was abolished in 1865 , but abolition did not automatically provide equal rights to African Americans. There were legal obstacles preventing their full citizenship and equal rights (Kymlicka, 1997). First of all, many Whites did not see Blacks as equals. A survey conducted in 1939 found that 47 percent of Whites believed that Blacks were biologically inferior. In this study, the data were collected from a national sample of 5000 white adults (Miller, 1997). To be sure, the constitutional amendment abolishing slavery could not change peoples' minds overnight. An example reflecting the mentality of White people on this matter is the "Separate but Equal Doctrine." This doctrine emerged from the Supreme Court decision of "Plessy versus Ferguson" in 1896. The story of this decision is briefly as follows:

Homer Plessy, a resident of the state of Louisiana, was a pas- 
senger on a train in 1892. The officer checking the tickets of the passengers asked Plessy to leave the White car and go to the car designated for Black people. Plessy, who was 1/8 (one-eighth) Black, sat down in a train car reserved for Whites only. Reasonably, Plessy was supposed to be classified as White, because he was 7/8 (seven-eighths) White. However, according to the "One-Drop Rule," Plessy was considered Black. This rule dictated that, even if a person had only one-drop of non-white blood, that person must be classified as Black. Plessy defended himself by arguing that slavery was abolished almost thirty years prior, and since Blacks and Whites were equal, he had the right to sit in any car he chose. As such, he rejected the officer's request, did not leave the car, and was arrested. Plessy took his case to the local court, which decided that he did not have right to travel in the car for Whites. He took the case to the Louisiana Supreme Court, but the court approved the decision previously made by local court. Plessy then took the case to the United States Supreme Court, which is the highest court in the country. The U.S. Supreme Court approved both decisions of the lower courts by saying that the state had the right to create separate facilities for their citizens as long as the facilities were equal. The "Separate but Equal" Doctrine emerged out of this decision and was adopted nationwide. In this decision, the historical practice of the separation of facilities for Whites and Blacks found a legal foundation. Whites and Blacks were legally separated in almost every aspect of life-private and public-from trains to schools, parks, hotels, restaurants, cafes, bars, and buses. In other words, since many Whites did not see Blacks as equal, they did not 
want Blacks to be around them. The Plessy vs. Ferguson decision of 1896 was abolished in 1954 by the Brown v. Board of Education of the U. S. Supreme Court. ${ }^{3}$

In the history of non-white minorities in America, there are many events, laws, and court decisions similar to the ones briefly cited above. For example, Chinese immigrants were invited to America to work on the construction of the railroad. After the construction ended, they were asked the leave the country. Some left, but most did not. Prejudice and discrimination ensued against them. A Chinese Exclusion Law was ratified in 1894, and they were forced to leave the country. Native Americans were labeled as sewage and un-civilized. They were destroyed through wars, and the Natives who weren't killed were forced to live in specified areas called "Indian Reservations," where European missionaries worked to convert them to Christianity. The children of Native Americans were enrolled in boarding schools to accelerate their assimilation to American culture. In these schools, the use of Native American languages was forbidden. These youth were not even allowed to visit their families (Banks, 2005). Today, Hispanic Americans are the largest minority group in America. They include many ethnic groups from the countries in Latin America. The largest among them are Mexican Americans. In the history of Hispanic Americans, there have been many oppressive and discriminatory events. For example, at the end of the U.S. and Mexican War in

\footnotetext{
3 The U.S. Supreme Court cases "Plessy v. Ferguson" and "Brown v. Board of Education" are widely documented in both printed media and Internet. A Google search by using the titles of the court decision provides information on these cases.
} 
1846, Texas was included in the U.S. territory. Later, by the purchase of eight southern states where people native to Mexico resided, a large group of Mexicans were forced to become minorities in the U.S. (Johnson, 1997). Overall, Hispanic Americans are not equally represented in governmental institutions, and their income and educational levels are lower than White Americans (Banks, 2005; Bigler, 2006; Statistical Abstracts of the U.S, 2012).

The Melting Pot has not served non-white and non-European Americans as it did for White immigrants from Europe (Steinfield, 1970). American scholars and politicians of the $18^{\text {th }}$ and $19^{\text {th }}$ centuries hardly cited the names of non-white ethnic groups among the groups forming the content of the American Melting Pot. They considered the non-white groups racially and culturally inferior (Miller, 1997; Hall, 1912). However, regardless of what the White Americans have thought and done, the Melting Pot assimilation policies have also served at different levels for the non-white ethnic groups. Over the centuries, these non-white ethnic groups all have identified themselves with the American nation. Today, in terms of the strength of their identification with America, there are some differences among the racial and ethnic groups, but all want to keep America united (Sidanius, Feshbach, Levin, and Pratto, 1997).

\section{The Salad Bowl: A New Metaphor}

Although many terms have been suggested to replace the metaphor of the Melting Pot with a new metaphor that better represents the process of ethnic interactions and assimilation in American society, 
the metaphor of Melting Pot has survived. However, during the last several decades, one of the suggested alternative terms-the Salad Bowl-has gained popularity and become the symbol of a new trend in approaching cultural diversity. According to the defenders of the concept of the Salad Bowl, America should not be a Melting Pot, but rather a Salad Bowl. The Melting Pot justifies the assimilation of minority cultures for the sake of creating a homogeneous society with a common culture. Regardless of rhetoric about cultural interaction and collaboration in the formation of a new culture, history shows that almost always minority cultures have been assimilated, and majority cultures have survived and dominated. According to proponents of the Salad Bowl metaphor, every culture, regardless of the number of people within it, is valuable. Cultures are neither superior nor inferior to one another. Every culture offers a different solution to the same human problems. Cultural diversity should not be assimilated but rather celebrated. However, to live as a strong and democratic nation, all groups in a society need a common language, a common knowledge base of history and literature, and a set of common values bonding them together. For example, in a democratic society, ethnic groups can keep their diverse features, but they need to know a common language to communicate and understand one another. For the recognition of cultural diversity, the metaphor of the Salad Bowl is more humane than the Melting Pot. In a salad, there are various ingredients (cultures) and when they are mixed with a dressing, the salad mixture tastes better than any single item within it. The taste of the dressing in salad (common values) is enriched by the contributions of the ingre- 
dients. Items in a salad are mixed, but the integrity of the individual ingredients is not destroyed; each ingredient enriches the taste of the other, and the taste of the dressing bonds them together. There is a growing trend in the U.S. to describe America as a Salad Bowl. However, in the mind of most Americans, America is still a Melting Pot.

\section{Nation Building in Turkey and America}

In their experiences of nation building in a new land, Turks and Americans have some similarities. For example, both immigrated to their current homeland-Turks mostly from Asia and Americans mostly from Europe, Africa, and Asia. Both conquered their homelands. There are also various differences between them. For example, about one thousand years ago, after the "Malazgirt Victory" against the Byzantium Empire in 1071, Turks began migrating in large groups to Turkey. As European ethnic groups about 500 years ago, Americans began immigrating to America. They conquered Native Americans and Hispanics, and, in 1776, declared their independence.

Regarding the assimilation of ethnic groups within each respective country, a significant difference between Turkey and America is related to their forms of government. America was established as a democratic nation-state. The Turkish states in Anatolia, the Seljuks, and the Ottomans were empires. They were not nation-states. The Turkish states did not have a policy for creating a homogeneous nation by assimilating minority groups, nor were they concerned about losing control of their land to new immigrants from different ethnic backgrounds. The new immigrants coming from Asia were already 
Turkish kin. On the other hand, American leaders and intellectuals were concerned about the growing diversity of immigrants and pushed for policies to assimilate the immigrants. For example, 28 million immigrants came to the U.S. between 1820 and 1912. About one-third of these immigrants were White while two-thirds of them were of different races. American leaders and intellectuals were concerned about the difficulties of their assimilation (Hall, 1912). As consistent with their religion, the Seljuk and Ottoman Empires accepted all Muslim groups as their brothers, regardless of their race and ethnicity. Also, as consistent with their form of state, that is, as an empire, they allowed the non-Turkish and non-Muslim groups in Anatolia to keep their cultures. A policy of assimilation did not exist in the Seljuks and Ottomans. Over the centuries, some of the non-Turkish and/or non-Muslim groups within these empires continued practicing their cultures, religions, and languages.

The Republic of Turkey, which was established after the collapse of the Ottoman Empire at the end of the First World War, is a nation-state. In the $19^{\text {th }}$ and $20^{\text {th }}$ centuries, the nation-state was a universal trend-a prestigious and dominating concept in the mind of politicians and intellectuals. The nation-state was seen as a necessity in order to have a strong economy and democratic order. As the era of empires ended, and all developed nations worked hard to establish or strengthen their nation-states. America, France, Germany, Italy, England, and many other countries were concerned about creating homogeneous nations with common cultures, languages, ideals, and values. 
The Republic of Turkey, during the decades following its establishment in 1923, looked to and followed developed nations. As a new state, Turkey was concerned about its unity, well-being, and future and wanted to use public schooling, like all advanced nations of that era, to strengthen its national unity.

\section{Is Turkey a Melting Pot or Salad Bowl?}

Is Turkey a Melting Pot or Salad Bowl? There is no direct answer to this question. Turkish tribes from central Asia dominated the formation of the culture of the Turkey of today (Öztuna, 1977). The immigration from Asia to Turkey lasted several centuries. On the way to Turkey, immigrants met and interacted with different nations and cultures. Also, there were some non-Turkish Muslims as well as non-Turkish and non-Muslim communities living in Turkey. These diverse communities kept their languages and cultures.

It is hard to generalize, but it is likely that some groups adopted one another's culture, and some of them were melted into the culture of the majority. Also, it is very likely that the ratio of cultural assimilation was high among the groups from the same racial and religious background, such as Turks and Kurds, as has been the case among white and Christian groups in America.

It seems that the ethnic blending that occurred in Turkey was different from that which occurred in America. In Turkey, racially white and religiously Muslim Turks and Kurds lived together for one thousand years and blended in many ways. Their "blending" looked 
different than that of the "blending" of Americans. This difference is due to the fact that the Kurdish community in Turkey has conserved its culture and speaks its native language. This is also the case for the Arabic community living in Turkey. On the other hand, as explained above, in America, white and Christian groups are almost completely melted into the majority culture. They neither practice their native culture nor do they speak their native language. In this sense, Turkey is neither a Melting Pot nor a Salad Bowl. The ingredients mixed in a Salad Bowl, if desired, can be divided and served separately. Each ingredient can function independently. However, the ingredients that comprise the Turkish nation today-particularly Turks and Kurds-are so mixed through intermarriage and cultural commonalities that their separation is impossible. Separation by force or by politics may not serve the self-interest of any party.

\section{What Serves Kurdish Self-Interest in Turkey: Dividing or Unify- ing?}

The most important factor that motivates people to social action is their self-interest, which comes in many forms, such as economic, honorific, political, religious, personal, social group related, ethnic group related, national, and the like. However, the motivation originated by any self-interest is directed, supported, accelerated, or curbed by ideas, which can be based on values, beliefs, norms, rules, and traditions. Any social action cannot be understood without understanding the motivation behind it (Weber, 1978; Özcan, 1996). In this section, I will discuss the motivation and ideas behind the actions and disposi- 
tions of Kurdish and Turkish actors.

Today, a significant problem in Turkey is terrorism by the separatist PKK-a group of Kurdish terrorists whose ultimate goal is to divide Turkey and establish an independent Kurdish state (Bengio, 2011). The PKK has been fighting against the Turkish security forces since 1984. These terrorists number at an estimated five to ten thousand. Though their number is not huge, they have been able to influence the part of the Kurdish population that supports them. We do not know the exact number or percentage of Kurdish people who would like to have an independent state.

At this point the question to be answered is: What serves the Kurdish self-interest in Turkey? We can categorize self-interests into three groups: economic, honorific and political. Let's look at the each category of self-interest for both sides:

(1) Can the Kurdish citizens of Turkey economically improve if they establish a Kurdish state in the eastern part of Turkey? It is hardly possible to say yes to this question because we know from relevant statistics that the government spends more money on the eastern part of Turkey than the revenues collected from that region. As for the Turkish side, it could be economically beneficial because spending for the infrastructure and military in that region might be reduced or even eliminated. However, if for any reason these Kurdish citizens were provided less economic opportunities than the citizens living in the other parts of Turkey, then this unfairness must be corrected as soon 
as possible.

(2) Can the Kurdish citizens of Turkey have higher honor, prestige and social status if they establish their own state? If the Kurds in Turkey are second-class citizens, or if they are considered as racially and culturally inferior as blacks, Native Americans, Hispanics, and Asians were once considered in America, then the answer is yes. Of course, it is possible to find isolated events in which some Kurds were treated unequally or not honored appropriately. However, social science requires the analysis of patterns of events, not merely purposefully-selected ones. In fact, it is possible to find isolated events of unequal treatment for everybody in Turkey, regardless of their ethnic background, religion, or social class. If we look at the one thousand years of history of the Turkish and Kurdish people in Anatolia, a frequently used theme is their brotherhood, such as during the Seljuk and Ottoman empires, when their religious brotherhood was emphasized (Ozer, 2009). In the Republic period, they became the equal citizens of Turkey like everybody else. The Turkish constitution does not provide any individuals or groups with higher or lower social status on the basis of any ascribed characteristics. On the other hand, in the first American constitution of 1787, slavery was accepted as a legal institution. Although later in 1865 the constitution was amended, until the 1950s and 1960s, Blacks were not allowed to attend schools with Whites; Blacks were not permitted to eat together with Whites in the same restaurants; and thousands of Blacks were lynched.

Another strong indicator showing that there is no a social status 
problem for the Kurdish people in Turkey is the ratio of intermarriage between Turks and Kurds. As explained above in the section about demographic facts, according to KONDA's findings, 40.9 percent of the 6,345,000 Kurdish adults are the relatives of Turkish people. This means that these people see one another as equal in social status. However, if Kurdish people think that Turks consider them inferior, then Turkish people should do whatever it takes to fix this problem and sincerely display their brotherhood. Neither Kurds nor Turks can have higher honor by any kind of separation.

(3). Can the Kurds in Turkey have more political power if they establish their own state? The issue of political power can be looked at from different perspectives. If, in a country, a group is forbidden from participating in the decision-making process, this deprivation can motivate them to struggle to gain decision-making power. Are the Kurdish citizens of Turkey deprived of their rights to participate in political processes? It is obvious that they have the same rights as all other Turkish citizens. In the Turkish Parliament, a Kurdish political party openly defends its ideas. In a speech in America in 2008, the Prime Minister explained that his party was comprised of 70 representatives of Kurdish background. There are also Kurdish representatives in other political parties. There are many elected Kurdish mayors serving the cities mostly in the eastern part of the country. Two Turkish presidents, Cemal Gürsel and Turgut Özal, were of Kurdish ancestries. Like all other citizens, Kurdish citizens of Turkey can be elected to any political position. Currently in the Turkish Parliament there is a 
pro-Kurdish political party. Also, Kemal Kıliçdaroğlu, the leader of the main opposition party, is a citizen of Kurdish and Alevi (Shia) descent. Interestingly, he was elected to the current position by the votes of delegates of Turkish descent (Economist, 2010). The Kurdish citizens of Turkey are very active in politics and are able to hold high level positions.

In the context of the conflict in Turkey, the declared goal of the Kurdish militants is to establish an independent state in which they have political power and sovereignty. It should be remembered that a universally established norm of gaining political independence is that an ethnic group must have the highest level of force available in order to defeat other forces fighting to gain control over a given territory. In other words, the norm is that the national sovereignty be gained by force. This norm requires that an ethnic group struggling for sovereignty should be able to dictate its will on others and to have others recognize the ethnic group's sovereignty. Having said this, we can ask: Can the Kurdish guerillas dictate their will on the Turkish army? Obviously, the answer is no. There is no possibility that the Kurdish terrorists can defeat the Turkish security forces. If they could do this, then they could divide the country and possess their own sovereignty, political independence, and decision-making power. Since there is no hope to defeat the Turkish security forces, the struggle of the Kurdish militants to gain sovereignty by using terror is self-destructive. It does not serve the self-interest of neither the Kurdish nor the Turkish people. 


\section{Conclusions}

Racial and ethnic groups from all over the world have come to America to create a new nation and culture. Their history on the North American continent is less than 500 years, but they have been blended and united as a nation. They learned to be American. Likewise, the Turks and Kurds have lived in the same homeland for more than one thousand year. The similarities between the Turks and Kurds are more ample than the similarities between the racial and ethnic groups in America, which have come from all over the world and from many different backgrounds.

Social realities are more complex than the metaphors used to explain them. There is no perfect "pot" melting everything within it, nor is there a perfect palette artfully blending all colors. America is still dealing with racial and ethnic prejudice and discrimination as well as large social class differences. Turkey, on the other hand, has an ethnic group attempting to divide the country by way of an uprising marked by terrorism. In America, there are political groups and non-governmental organizations striving to eliminate these problems and improve the American standard of life. However, none of the groups or organizations is using terror as a tool to gain political rights, economic advantages, or high social status. None of them wants to divide America and establish its own independent state. None of them is requesting the use of its own language as the language of instruction in the public schools that they attend. They strive to solve problems without destroying the American unity. They are aware that keeping 
America united and powerful is in their best interest. They know that weakening and dividing America will harm their well being. The Kurdish citizens of Turkey who want to divide the country by force or by politics must re-think how harmful it would be for their own self-interest.

\section{Acknowledgment}

The author would like to acknowledge Shelby Ferreira for her work in editing this text. Shelby graduated from both Providence College and Western Governor's University. At present, she is pursuing a Ph.D. in Education. Her research interests include education for social justice, education in prisons, critical pedagogy, and prison abolitionist ideology.

\section{References}

Ağırdır, B. (2008). Kürtler ve kürt sorunu (Kurds and Kurdish question). Retrieved, July 5, 2010, from www.konda.com.tr.

Banks, J. (2005). Ethnic studies. New York: Alien and Bacon.

Banks, J. (2007). Multicultural education. New York: Alien and Bacon.

Banks, J. (Ed.). (2004). Diversity and citizenship education: Global perspectives. CA: Jossey Bass Pub.

Bengio, O. (2011). The "Kurdish Spring" in Turkey and its impact on Turkish foreign relations in the Middle East. Turkish Studies, 12(4), 619-632. 
Bigler, E. (2006). In search of America: Latina/os (Re) constructing the U.S.A. Faculty Publications, 15(25), 239-257. Retrieved, July 5, 2010, from

http://digitalcommons.ric.edu/facultypublications/254.

Brislin, R. (1993). Understanding culture's influence on behavior. New York: Harcourt Brace Jovanovich College Pub.

Crevecoeur, J. H. J. (1957). Letters from an American farmer. New York: Penguin Group.

Curti, M. (1946). The roots of American loyalty. New York.

A new Kemal: Kemal Kilıçdaroğlu gives new hope to the Turkish opposition. (May 27, 2010). Retrieved, March 20, 2011, from www.economist.com/node/16219855.

Gleason, P. (1964). The melting pot: Symbol of fusion of confusion? American Quarterly, 16(1), 20-46.

Hall, P. F. (1912). The future of American ideals. The North American Review, 195(674), 94-102.

Harris, M. \& Johnson, O. (2000). Cultural anthropology (5 $5^{\text {th }}$ ed.). Boston: Allyn and Bacon.

Huntington, S. (2004). Who are we? New York: Simon and Schuster.

Johnson, K. R. (1997). 'Melting pot' or 'Ring of fire'?: Assimilation and the Mexican American experience. California Law Review, 85(5), 1259-1313.

Klein, R. G. \& Edgar, B. (2002). The dawn of human culture. New York: J.Wiley and Sons. 
Kymlicka, W. (1997). The rights of minority cultures. Oxford: Oxford University Press.

Miller, S. (1997). An American imperative. Connecticut: Yale University Press.

Ogbu, J. (2003). Black American students in an affluent suburb: A study of academic disengagement. Mahwah, NJ: Lawrence Erlbaum Associates.

Özcan, M. (1996). Improving teacher performance: Toward a theory of teacher motivation. Paper presented at the American Educational Research Association (AERA) annual meeting. New York, April 8-12.

Özer, A. (2009). Beş büyük tarihi kavşakta Türkler ve Kürtler, Ankara: Hemen Kitap Yayını.

Öztuna, Y. (1977). Büyük Türk tarihi. İstanbul: Ötüken Yayınevi.

Sidanius, J., Feshbach, S., Levin, S. \& Pratto, F. (1997). The interface between ethnic and national attachment: Ethnic pluralism or ethnic dominance? The Public Opinion Quarterly, 61(1), (Special issue on race), 102-133.

Steinfield, M. (1970). Cracks in the melting pot: Racism and discrimination in American Society. California: Gleneoe Press.

United States Census Bureau (2010). Statistical Abstracts of the United States. Retrieved, June 3, 2010, from

http://www.census.gov/prod/www/statistical_abstract.html

United States Census Bureau (2012). Statistical Abstracts of the United States. Retrieved, October 3, 2014, from

http://www.census.gov/prod/www/statistical_abstract.html 
Weber, M. (1978). Economy and society. CA: U. California Press.

Weber, M. (1995). Protestant ethic and the spirit of capitalism. New York: Penguin Classics. 